\title{
The Challenges before Higher Education for the Composite Growth of a Sustainable Society
}

\author{
Wyzwania stojące przed szkolnictwem wyższym \\ w kontekście kształtowania złożonego \\ zrównoważonego społeczeństwa
}

\author{
Anupama Purohit \\ Department of Humanities and Social Sciences, Indian Institute of Technology (ISM), Dhanbad, India \\ E-mail: anupama.purohit666@gmail.com, ORCID: 0000-0002-8432-3987
}

\begin{abstract}
A society is a large composite structure moulded by many interconnected non-autonomous entities. As the growth of the society is an inevitable continuous process, its structure and so also its demands keep on changing. This alteration, yields up many challenges to be met by the individual of a society. The sustainable growth of society, along with its diversity and disparities, needs a holistic approach to development. Therefore, there is a demand of fostering a durable human resource. The higher education besides being value addition to a person's cognitive ability, must enhance the readiness to face any problem in life with sufficient empirical competence. The greatest challenge before higher education is to inculcate humanitarian values, civic knowledge and sensitivity towards other life forms and the environment in a learner; so that s/he can realise her/his obligation to the social and natural environment.
\end{abstract}

Key words: composite society, humanitarian values, civic knowledge, sustainable growth

\section{Streszczenie}

Społeczeństwo to wielka złożona struktura utworzona przez wiele połączonych ze sobą nieautonomicznych bytów. Ponieważ rozwój społeczeństwa jest nieuniknionym procesem ciągłym, jego struktura, a więc także wymagania, ulegają ciągłym zmianom. Ta zmiana stawia przed jednostką społeczną wiele wyzwań. Zrównoważony rozwój społeczeństwa, wraz z jego różnorodnością i dysproporcjami, wymaga holistycznego podejścia. Dlatego istnieje potrzeba wspierania trwałych zasobów ludzkich. Wykształcenie wyższe oprócz tego, że stanowi wartość dodaną do zdolności poznawczych osoby, musi zwiększać gotowość do stawienia czoła każdemu problemowi życiowemu z wystarczającymi kompetencjami empirycznymi. Największym wyzwaniem stojącym przed szkolnictwem wyższym jest wpajanie uczącym się wartości humanitarnych, wiedzy obywatelskiej i wrażliwości na inne formy życia i środowisko; tak, aby mogli oni realizować swoje zobowiązania wobec otoczenia społecznego i naturalnego.

Słowa kluczowe: społeczeństwo złożone, wartości humanitarne, wiedza obywatelska, zrównoważony wzrost

\section{Introduction}

A society is a large composite structure moulded by many interconnected non-autonomous entities. As the growth of the society is a continuous process, its structure and so also its demands keep on changing. This alteration, especially in the post-modern world, crops up many challenges to be met by the individual of the society. The sustainable and composite growth of society, along with its diversity and disparities, needs a holistic approach to development. Therefore, there is a demand of building up a strong human resource which would be supported by a highly moral value system to face any problems in the society. Education is the process of change in the human beings - mentally, physically and emotionally. The Greek philosopher Confucius had the vision that, if you think in terms of a year, plant a seed; if in terms of 
ten years, plant trees; if in terms of hundred years, teach the people (brainyquote.com, 2021). Therefore, we have to reconsider our commitment and strategy to higher education because any problem of the society is a challenge for the higher education system. The Nobel laurate Nelson Mandela in his address entitled Lighting your way to a better future (2003) had said, education is the most powerful weapon we can use to change the world (Nelson Mandela Foundation, 2021).

This paper contains many grass root level examples to make us realise what are the factors impeding the sustainable growth of society, ponder over the lacunas in the existing higher education system and few suggestions regarding how to face the challenges through reformation in it. The challenges to the higher education system stem from many sectors social discourse, lack of ethical values and civic sense, economic system, rigid mindset, underdeveloped human resource, deterioration in the standard of education, the tension between the socio- cultural need and the pressure to compete with the global standard etcetera. Secondly, the requirement of a composite society for sustainable development is pondered upon. Thirdly, several propositions are made in this direction. The suggestions are general in nature and are applicable to all most all the countries for the balanced growth of their societies. Finally, the pivotal role and importance of literature in higher education is established.

\section{The Challenges}

The problems faced by the society keep on shifting. Earlier it was war among small or big nations ruled by the kings and the emperors, then colonialism and now neo-colonialism; earlier it used to be the terror of the pirates, the burglars, now is the fear of the terrorists. The hostility between various social classes of the past has been replaced by the pressure groups these days. Earlier kings' favourites are replaced by politicians' vote banks; superstitions are replaced by experimentations like drug addiction. The fundamental vices and the cardinal virtues are elemental in human nature; both the angelic as well as demonic sides are there in our character. It is up to us how we are trained to explore ourselves.

\subsection{Social}

The nature of the social problems varies at various levels. The local level problems of which a layman is aware of are - inflation; spread of endemic diseases; natural calamities; communal riots; child trafficking, child labour, child abuse; sexual harassment; chit fund scams; uneven economic distribution; environmental hazard, environment pollution; brain drain; rampant corruption, black money possession; discrepancies on caste, gender, birth, colour basis etc. Even if legal provisions are made against some of these, they have not been proved to be much effective. Irrespective of education the mass reacts to such situation in adverse spontaneously. Here is the lack of a humanitarian value. Equality, fraternity and Liberty are only few idealistic terms very often confined to the books. It seems that we have not learned anything from history because wittingly history is repeating itself. Frederick W. Robertson says, instruction ends in the school-room, but education ends only with life (brainyquote.com, 2021) and the continuation of the above problems confirms that people of our society are not well educated.

\subsection{Lack of civic sense}

Again, the failure of our higher education system to build up our character can be demonstrated through the few following examples. Children reluctant to take care of their old and alien parents; people making public place dirty by disposing polythene and garbage; writing, inscribing and damaging the floors, walls of public structures and the national monuments; the street begging culture of able young people; commercialisation of religious institution- grace of God in proportion to money offered; rise in the of the fake babas (so-called spiritual leaders) and their blind supporters; beating animals for hedonistic pleasure; scolding and misbehaving servants; wasting electricity and natural resources like petroleum and water; ignoring a helpless accident victim on the road and indifference to the physically challenged people when they face difficulty at public places; breaking rules in the absence of the authority likeviolating traffic rules, unnecessarily blowing horn, cracking bombs, playing music loudly and creating civic inconveniences; breaking a queue due to impatience; wasting food, injecting hormones and colour to make the fruit size bigger and lucrative and so on. Again, violence during strike and damage to the public property; tearing pages from the library books; black marketing; child labour at home, restaurant and garage; using pesticides then plucking and selling vegetables before the required time period to earn money, hoarding consumer items and creating an artificial shortage are due to the blind hunger of greed etc. Such blunders can be committed by any insensible person- both an illiterate man and a highly qualified person. Can we call such person with high academic qualification well educated? We are so familiar to such nuisances that we ignore them. Sometimes they are not opposed deliberately and sometimes these are recognized as the normal course. These are such problems most of which do not come under the circumference of law and order so that a desired change can be brought by force in the society. Here people cannot be compelled. Here comes the role of higher education that can impel more mature and skilled minds to guard the ethics, value system and tradition while introducing the changes that can make life better in a com- 
patible way with the prevalent system. Even if democratic system, freedom of expression right to information and well-articulated constitution is available to us these benefits are not reaped properly due to lack of awareness.

\subsection{Lack of ethical values}

It seems that getting highly educated mass in the current education system is not the solution to the problems concerning ethical issues. It is not that those who commit such blunders in the society are not aware of what they are doing; rather ironically, they are proud of doing all these evils to promote their interest. Good conducts are to be infused in to the behaviour pattern of the people through education. Only empowerment of human resource is not enough; how the power is being used is to be watched and directed. The person who had explored the potentiality of atomic energy was a scientist. How to use that energy - as atom bombs to devastate a civilization, or to possess the potential to frighten others, or to use that in the nuclear reactor to produce electricity is our choice. Roth firmly asserts that college teaches young people to think and to engage, allowing them to better themselves and their societies. In his vision, liberal education matters far beyond the university because it increases our capacity to understand the world, contribute to it, and reshape ourselves. (Roth, 2014).

\subsection{Economic disparities}

As far as basic level education is concerned, it is not much expensive, but for higher education, the government has to invest a lot. It is the demand of the hour from each government, that they should venture into higher education segment to convert the burden of population growth into human resource. Economic growth of each person and a country as a whole directly depends on the education level. It helps to alter the structure of a society from agrarian to non-agricultural. This implies that with help of the technology (in an environmentally friendly way), with a smaller number of work force one can produce the desired amount of crop. The rest of the human resource can be utilised at some other sectors. Higher education is the strongest, sturdiest ladder to increased socio-economic mobility (weforum.org, 2015) as articulated by Drew Gilpin Faust, an American historian. With access to higher education for all, it can be hoped that the economic gap in the society would be reduced.

\subsection{Human resource development}

In order to survive in the tough competition in the liberal market economy and with direct foreign investment in globalised world, a nation has to equip its human resource. Despite belonging to a developed country, Meg Whitman in an interview in ABC News on November 17, 2009 was expressing his concern regarding the future of the US as: because if you don't have a great workforce, a great higher education system, you're not going to have the next eBay, the next AmGen, the next, you know, Miasole, and not only California but America is going to fall behind a whole new competitive context which is obviously China, India, and other countries (ABC News, 2009).

This is a lesson for all the countries, drawing attention to the urgency of working upon human resource development to make the society sustainable.

\subsection{Deterioration in the standard of education}

The academic challenges in the higher education are the quality of the provided study environment- competent teaching faculty, world standard syllabus, giving place to new area of interest in curriculum, resurrection of traditional ancient knowledge, introducing smart class and interdisciplinary courses; good library facility, including e-library; correspondence course, lower cost of education; well-equipped laboratory; grants, scholarships, for the disadvantaged group, more investment in higher educational sector; guard against fake universities, paying attention to vocational training to produce skilled self- employers. No walk of life should be neglected by higher education system.

\subsection{Rigid Mindset}

It is a challenge for higher education to make people feel its own significance by bringing certain reform in its contribution according to the social need - in the academic field and cultural field. Following are some of the challenges faced by higher education system from society itself. Few orthodox people in the society due to their certain conservative notions regarding higher education accept it reluctantly. For example, girls are kept at home and are prepared for their marital life by doing household chores which they are supposed to do throughout their life. Certain faith, tradition and practices being designated superstition and unreasonable, evil thing offends the old orthodoxy. Often it appears that the older generation's faith is challenged to answer the present questions. Their age-old rituals are mocked at as superstitions. Often it is heard that highly literate daughters-in-law are untameable. Therefore, a feeble resistance can be felt to the questioning spirit of higher education. Higher studies mean longer study carrier. It delays earning for the family for few years; whereas sometimes the poor economic condition of the family demands another helping hand for it. If there is some family business generally people do not opt for that because they do not realize the importance of further study. Often highly educated people get opportunity to go abroad for job but instead of returning home they prefer to settle there. Families who feel insecure regarding their possession of their children prefer not to provide higher education to their children. To some extent their lack of nationality is responsible for this. 


\section{Composite Growth of Society}

Usually, people cannot relate the knowledge gained from higher studies to their day today life beyond the basic skills they acquire at secondary level which is more general in nature. The cause of merge enrolment of students at universities of drop out and high levels is that most of the people cannot relate it to their social contexts and cultural practices. Without mass involvement in higher education a wholesale transformation in the society could not be accomplished. The composite growth of a society demands a proportionate growth of all the components and all the sections of the society, who should live together in harmony with each other and society as a whole. Thus, shrinking disparities and division of the society based on class, caste, clan, sect, faith, colour which indeed is one of the biggest challenges. The Nobel laureate R. N. Tagore had said: the highest education is that which does not merely give us information but makes our life in harmony with all existence (Rosca, 2015).

\section{Suggestions}

In higher education one gets the opportunity to specialize in one's area of interest at a mature state. However, roughly it can be divided into two partsthe preparatory section that is, graduation, post-graduation and the research part. Moreover, research can be basic research and development and inter disciplinary research. Development in any field is beneficial only when it is useful in the public interest and not in contradiction with other social issues.

The main branches of higher education are science, commerce and humanities. Science makes our living comfortable. Society does not exist without commodity so its tread and transport are dealt by commerce. The branch arts is alternatively called humanities because it carries humanitarian values. Sociology is the study of the nature of societies, its trends, needs; law is for justice; journalism is for awareness; psychology is the study of mental issues; and the role of philosophy is to contemplate; economics and political science are about way of the world; history teaches the lessons we have learned from the mistakes that were committed in the past; language provides us an opportunity to peep into and interact with other cultures; at last comes literature that deals with all the above mentioned now in the disguise of fiction. None of the branches of studies is as effective in cultivating humanism in a human being as the study of literature. Since childhood such values are injected into the tender mind of a child through fables, stories and anecdotes. During primary and secondary schooling these values are to be served before them further through education, group activities, team work. But as soon as higher education is started, specialization of the course begins and the gap among various branches of studies and its direct link with the day today life dwindles. Studies become more and more carrier oriented; the students read to score good result so that they can perform get seat at the next level or do well in the competitive examinations. One after another qualification is earned and with that eligibility to get better job is enhanced. The materialistic approach to life leads T. S. Eliot to say in The Rock: Where is the Life we have lost in living? Where is the wisdom we have lost in knowledge? Where is the knowledge we have lost in information? (Eliot, 1934).

Moreover, once Einstein had remarked, education is what remains after one has forgotten everything he learned in school (brainyquote.com, 2021). It is the trace that remains in us after years of formal training.

\subsection{Teacher training}

Queen Rania of Jordan has said, good teachers teach. Great teachers transform (weforum.org, 2015). One problem faced during the recruitment of teaching faculty for universities is that the posts are remaining vacant due to lack of eligible candidates. This reflects how the quality of education has gone down. Expansion of higher education system is the demand of the situation but that should not be done at the cost of quality of education. Immediate attention must be devoted to teacher training for the development of the faculties because, as Ron Lewis has held, ensuring quality higher education is one of the most important things we can do for future generation (brainyquote.com, 2021).

\subsection{Glocal syllabus}

Being global does not mean that one would neglect one's local needs. The reorientation of syllabus in the process of globalisation of education would keep us update with the new advancements and at par with other developed countries of the world. However, care must be taken not to neglect local language, geography, history and culture to save education from being abstract to the social context. It is advisable to gain the local knowledge at the preliminary stages of education and widen the scope of learning to the international level during the later phases of education, especially, higher education. Hence, the overall curriculum has to address glocal issues. At the research level of higher education, the motto should be to learn globally, and implement locally. Then only the benefit of the knowledge developed and preserved in any remote corner of the world can be accessible to others.

\subsection{Creating scope in the job market to learn new course}

Due to the emerging recognition of various professions private institutes are cropped up, palmistry, journalism and mass media, architecture, animation, interior designing, dress designing, sculptor, making cartoon, painting art schools are founded. For film industry, theatre, drama, mime acting schools are es- 
tablished; music schools are teaching how to play various musical instruments and reviving classical music and pop songs. All these are signs of a developed civilisation where people find leisure to indulge in artistic pursuits. If these knowledges would get the recognition and support of the universities, then they would thrive vibrantly.

\subsection{Work integrated learning approach}

Work integrated learning programmes facilitates highly effective in helping scholars uncover their true potential. This can be implemented only at higher education level. The benefits of work integrated learning are practical application of the theories learnt in the books, entering into the job market before the completion of the course, thus gaining additional work experience, building up a firm employability-base, developing self-awareness and comprehending career opportunities and the job market. Besides this, inter-disciplinary courses are beneficial in earning more than one degree for the students. They can be specialised in more than one specific subject. Thus, courses like integrated law, integrated MBA, biodiversity, biotechnology, polytechnics, comparative literature studies and so forth should be introduced at the university levels. These should be developed along with more specialisation like industrial economy, women studies, creative writing, rural management, cyber law, criminology, aeronautics to produce experts in each walk of life. Hence, more options should be opened before students at an early stage because these are subjects those can be handled after the general courses.

\subsection{Connecting course and Learning International lingua-franca}

In order to establish harmony among all the branches of higher studies at least one or two papers of other branches are to be introduced into the syllabus of a course. For example, at the graduation level all the students of science stream and engineering have to study papers on communicative English, environmental studies, population studies and cultural studies. Like that the students of arts have to go through computer education, reasoning and data analysis. Generally communicative English is kept as a paper in all most at all the branches of studies at the graduation level. But at post graduate level and after that no such provision is made. Whatever has done yet in this direction is not enough; more care should be taken to bridge the gap. At least one foreign language, should be made compulsory even in postgraduation because it is the sole medium to connect with the outer world. Being skilled in a widely spoken international language enhance one's communication ability to get connected to the major population on the earth, greater mobility and job opportunity.

\subsection{Equal opportunity for all}

Sometimes financial pressure of the private institutions and technical educations deprives many talents to opt for these branches. Whereas the government universities seat numbers are limited to accommodate students in large number, only the top performers are fortunate enough to get enrolled. Thomas Frank says, for profit higher education is today a booming industry, feeding on the student loans handed out to the desperate (brainyquote.org, 2021). Many fake universities are cropping up to cheat students and such activities has to be checked. Scholarship for bright students, financial aid for financially backward section, loan facilities for the poor and encouragement should be provided to the female students. There are provisions also but they are not well executed in time. However, keeping reservation for certain category while getting a seat at an educational institution or at job may be used as a strategy to encourage learning for that particular group, but it conveys a negative message for the rest. In fact, education has to be free throughout the career. Irrespective of the gender, caste, creed, faith, sect, community, nationality each human being should have equal access to education in their life. Then there would be no need of reservation at all. Thus, education would remain out of politics.

\subsection{Technological intervention in teaching}

Heavy use of technology is to be introduced in the higher studies as it has immense potentiality to carter the demand in the direction of sustaining our society. José Antonio Bowen, in Teaching Naked: How Moving Technology Out of Your College Classroom Will Improve Student Learning mentions that, time for reflection and interaction is a casualty of the digital age, and one of the primary goals of higher education should be to reclaim this time (Bowen, 2014). Digitalisation of education is more effective, the World Wide Web, e-education, e-books world's biggest libraries through e-library would be at the disposal of a common student. The COVID- 19 pandemic taught us a nice lesson in terms of the potentialities of virtual platforms. Many e-conferences and regular classes can be organised in a smooth manner. Subsequently, steps must be taken to make people access such online education.

\subsection{Distance mode of learning}

Sometimes due to their busy schedule and other issues, people do not get opportunity to pursue higher education, despite being interested in contributing their share for the social wellbeing. Introduction of courses in distance mode, along with e-learning run by various universities can exploit this opportunity. Such courses should be of short duration and the application of the theories taught are to be done side by side by project works, team works, workshops, seminars, field work, mini research works, exhibitions, internship for few months are to be done. These 
would develop group behaviour, fellow feeling, responsibility, carefulness, self-assertion among the scholars. Distance education is a boon for those who cannot attain class because of their inaccessibility to higher education at their locality.

\subsection{Physical training}

Physical education in the form of martial art, yoga, aerobics, self-defence training is also mandatory for the physical wellbeing of the students during graduation, but it is confined to pen and paper only; arbitrarily grades are distributed on the mark sheets against this criterion. Physical fitness would let a person help oneself, others. The awareness of physical fitness would draw attention to healthy habits, consuming organic products, inhaling oxygen rich air, maintaining a clean and eco-friendly environment. One would realise the importance of the flora and fauna and try to preserve them for one's own sustenance.

\subsection{Vocational training}

Each walk of life that fulfils social needs is significant. The culture of not to undermine any of the professions should be developed. Generally, aversion to agriculture is found among the young generation. It is alarming that in Japan the average age of a farmer is around sixty. If all the students would aspire to opt for only few professions like doctor, engineer, scientists, management professionals, chattered accountant, lawyers, civil servant then who shall be the farmer, cobbler, carpenter, plumber, making pottery, bangle maker, tailor, goldsmith, weaver, barber, working on jute, bronze, copper, silver and vehicle mechanic? Development of a skilled labourer can eradicate unemployment problem and fast and finished completion of their job leading to greater productivity. Usually, these professions practices are transmitted from ancestral family occupations. Why should such fields be relegated to the illiterates and unskilled stock? How many training schools are there for such professions? It is essential to teach vocational training alongside the general courses. The application of the theories taught in the classroom should be done by project works. Vocational education can create independent entrepreneurship self-employment.

\subsection{Revive Indigenous knowledge}

There are many communities in the world who have preserved their age-old indigenous knowledge in the form of culinary dishes, preparing spices, herbal medicines, body massage, body sculpting, handicraft, weaving, pottery and other handicrafts, architectural knowledge (vastu shastra and Feng sui), numerology, palmistry, acupressure etcetera. All these would extinct unless they are preserved and promoted. Loss of a such ethnic craft, is loss to the whole humanity. These must not be relegated as obsolete, rather these should be respected as these are scientifically based on experience of many generations. Transformation of heart can be achieved through the extra- curricular activity. This must be done through the mass involvement of the students in the cultural programmes conducted and promoted by the universities. It also includes the behaviour of the staffs of a university.

\subsection{Research oriented education}

Research should be directed towards long term sustainable development of society. It must not be like developing a composition of chemicals to suppress a health problem which may provide a temporary relief with a lot of side effects and selling them as medicine. Inter disciplinary researches should be encouraged for better social benefits. New scientific inventions and discoveries make our living comfortable, but our value system should be such that we would not permit us to become easy going and earn money at the cost of wellbeing of others. At Nasik, the grape farmers hesitate to consume the grapes they sell. The US had refused to import mangoes from India because of harmful pesticides particles were found in them. Like that being easy going people are using canned and packed food persevered by unpermitted harmful chemicals. The introduction of Green Revolution in Punjab and Haryana is a failure in so far as sustainable growth of agriculture is concerned. No doubt productivity had increased but heavy use of pesticides and fertilisers have damaged the natural fertility of the soil. Therefore, though scientific research and developments make our life comfortable, saves time, energy and cost effective, we have to be selective in adopting and implementing them in our life. It is to be watched that our environmental condition would neither get hamper at present, nor in the future due to a new found technology.

\subsection{Religious education}

In the fast-changing postmodern world where there is no constancy, no permanent solution of existential problems, only tentative reconciliation seems soothing, there is no faith that cannot be questioned in such circumstances if the elemental humanitarian qualities would be encouraged inside people the moral backbone of the society would provide it strength to face the present as well as the unpremeditated challenges. Religious education has to be introduced because no religion is anti-social and they all are based on a faith. The modern sceptical, rootless, faithless mind needs some solid support to save it from anarchy.

\subsection{Sensitivity towards other life forms and the en- vironment}

The ideology of Hindu Adweta Vedanta (non-dual principle) pleads for a pantheistic view. It says that all the beings, even non-living beings are essentially not different and separated, because they all embody 
the same essence of the God. Ayam nijah paroveti ganana laghuchetasam, udaracharitanantu vasudhaiva kutumbakam (The Maha Upanishad).

This means those who are mean, they think in terms of mine-yours; but broadminded people consider the whole world to be a single family. Here broadening of mind means being able to understand stand others' point of view and being tolerant to that. Only an enlightened mind can do so. One who realises this, that person never can harm or exploit others - human beings, animals and plants and damage the environment. Thus, the aim of higher education should be to, 'amaso ma jyotirgamaya (Brhadaranyaka Upanishada I.iii.28), lead us from darkness of ignorance to the enlightenment of knowledge.

\section{Value education through Literature}

Finally, the most important challenge before higher education is to make society a better place to live in a society free of fear, actual or potential terror, extremist behaviour, corruption, and disharmony. Scientific developments have made life much easier but it is doubtful whether with the technical progressions and transformation, human being has earned more happiness and achieved more wisdom than one was a century ago.

According to a Chinese anecdote, once there was a king. He had a retired minister who was living peacefully in a joint family of a few hundred members. Being curious, the king visited his house. The king carefully observed the conduct of the members. Every one attentively did his job and there was mark of pleasure and satisfaction in every face. The king was much impressed and urged the retired minister to write down all the aspects the family nurtured as a result of which it was united and everyone lead a peaceful secured and prosperous living. The wise minister wrote nothing but one word repeatedly. The word was tolerance. All the social evils we encounter have different causes but all the causes have the common root and it is intolerance. Education is simply the soul of a society as it passes from one generation to another (brainyquote.com, 2021).

The greatest challenge before higher education and to a great extent education in general, is how to inculcate humanitarian values in the human mind. It is easy to teach $(a+b)^{2}=a^{2}+b^{2}+2 a b$ but how can one teach somebody compassion and what a person in pain feels like! The lesson taught in history retells us what has already happened; religious teachings, metaphysics sermons preach us dos and don'ts. But art and specially literature narrates meticulously what should have been, the most ideal and perfect situation through the fictional mask of narration. A live performance of a human struggle with social problem on stage moves us, the performance of the actor in films makes us laugh and shed tear as well. These moving, smiling at the favourable situation of the character with, and shedding tear at a tragic situation, laughing at folly, aversion at the undesirable unacceptable sights is nothing but our sympathy and empathy for the fictional characters with whom we unwitting get involved due to our suspension of distrust. Film sessions and cultural programmes should be organised at university because in them we get the most vibrant representation of emotions that can move us. These make us tender, sensible and acquaint us with the human in us.

According to Aristotle, educating the mind without educating a heart is no education at all (goodreads.com, 2021). Here Kabir's doha (a form of selfcontained rhyming couplet in Hindi poetry composed in Mātrika metre) seems to be the most appropriate simile to describe a person with high academic qualification but devoid of humanitarian value as, Bada Hua To Kya Hua, Jaise Ped Khajoor Panthi Ko Chhaya Nahin, Phal Laage Atidoor (santkabirdas.blogspot.com, 2021).

This means a person may be a highly talented wise person but if his rich knowledge cannot be served for the wellbeing of the society and he became self-centred then that person is like that of a tall date tree which does not provide shadow to the tramp and whose fruits are not accessible easily. Higher education enhances a person's mobility and job opportunity. Gautama Buddha had compared education to that of Kamdhenu, the Hindu mythical cow that fulfils all wishes, it helps one to realise one's dreams in another land, it protects one from alienation and it earns admiration, and it is a hidden treasure of a person.

\section{Conclusion}

The challenges before higher education are to inculcate humanitarian values and civic sense in learners, so that they can realise their obligation to the society and fellow human beings. While creating equal opportunity for all, technological intervention in teaching and distance mode of education are to be considered to bring all under the scope of higher education. Reviving indigenous knowledge and promoting vocational training would connect generations and research-oriented higher education would vent innovations, based on the previous knowledge. Creation of a work-integrated learning approach, vocational training and generating scope in the job market would make room for learning new courses. With introduction of a glocal syllabus, breaching the gap among various branches of studies and learning international lingua-franca to remove the barriers in communication, higher education would adopt an all-inclusive approach towards social development. Then only they shall serve the society with the mantra of Bahujana sukhaya bahujana hitaya cha (The Rigveda, for the happiness of many, for the wellbeing of many). The physical training and religious education would tend the corporal and spiritual dimen- 
sions, respectively. A balance has to be maintained between the knowledge gained from higher education and its empirical benefits for the construction of a sustainable society. Finally, morality, philosophy, value system, lessons learned from histories can be conveyed effectively especially through the fictional mask of literature. It would impel a person to become sensitive towards other life forms and the environment and tolerant to other point of views leading to composite growth of a sustainable society.

\section{References}

1. ABC News, 2009, Meg Whitman, https://abcnews. go.com/Politics/transcript-abc-news-interviewsmeg-whitman/story?id=9126169 (19.11.2009).

2. BOWEN J. A., 2014, Review of the book 'Teaching Naked: How Moving Technology Out of Your College Classroom Will Improve Student Learning, Journal of College Student Development 55(7): 751753. DOI:10.1353/csd.2014.0071.

3. Brainy Quote, Chesterton, https://www.brainyquote. com/quotes/gilbert_k_chesterton_104904 (19.01.2021).

4. Brainy Quote, 2021, Confucius, https://www.brainy quote.com/quotes/confucius_391333 (06.01.2021)

5. Brainy Quote, 2021, Einstein, https://www.brainy quote.com/quotes/albert_einstein_108304 (06.01.2021).
6. Brainy Quote, 2021, Frank, https://www.brainy quote.com/quotes/thomas_frank_484679 (06.01.2021).

7. Brainy Quote, 2021, Lewis, https://www.brainyquote. com/quotes/ron_lewis_337487 (06.01.2021).

8. Brainy Quote, 2021, Roberts, https://www.brainy quote.com/quotes/frederick_william_roberts_17502 3 (06.01.2021).

9. ELIOT T. S., 1934, The Rock, Faber \& Faber, London.

10. Goodreads, 2021, Educating the mind without the mind, without educating the heart is no education, https://www.goodreads.com/quotes/95080-educating-the-mind-without-educating-the-heart-is-no-education (06. 01. 2021)

11. KABIR Das ke Dohe, santkabirdas.blogspot.com (06. 01.2021).

12. Nelson Mandela Foundation, 2003, http://www. mindset.co.za/ (06.01.2021).

13. ROSCA O., 2015, The Role of Agencies of Socialization for My Social Entity Development, https:// www.researchgate.net/profile/Oxana_Rosca/publication/279781158 (04.01.2021).

14. ROTH M. S., 2014, Beyond the university: Why liberal education matters. Yale University Press.

15. The Maha Upanishad.

16. The Brhadaranyaka Upanishad I.iii.28.

17. The Rigveda.

18. World Economic Forum, 2021, Top 5 quotes on education, https://www.weforum.org/agenda/2015/03/ top-5-quotes-on-education (06.01.2021). 